\title{
Immune response in families of children with acute lymphoblastic leukaemia
}

\author{
D. I. K. EVANS \\ From the Department of Child Health, University of Manchester, and the Department of Haematology, Royal Manchester \\ Children's Hospital, Pendlebury, Manchester
}

\begin{abstract}
Evans, D. I. K. (1973). Archives of Disease in Childhood, 48, 441. Immune response in families of children with acute lymphoblastic leukaemia. The immune status of 33 mothers, 17 fathers, and 14 sibs of children with acute lymphoblastic leukaemia was studied with the following tests: peripheral blood lymphocyte counts, lymphocyte transformation with phytohaemagglutinin, serum immunoglobulin levels, isohaemagglutinin titres, and levels of antibody to herpes simplex and EpsteinBarr viruses. No significant abnormality was shown by these tests, with the exception of a lymphocytosis detected in parents at an early stage of their child's disease. The significance of these findings is discussed in the light of the concept that viral infection relates to the aetiology of childhood leukaemia. It is concluded that there is no defect of immunity in these families.
\end{abstract}

The families of patients with immune deficiency states not infrequently show an abnormality of immunity, particularly of the immunoglobulins, yet this abnormality is often not identical with the defect in the propositus (Goldberg, Barnett, and Fudenberg, 1968; Soothill, 1968; Stocker, Ammann, and Rossi, 1968; Ablin, 1971). It is now well recognized that malignant disease occurs with unusual frequency in patients with immune deficiency disease, and ataxia telangiectasia, in particular, predisposes development of lymphoma and leukaemia (Gatti and Good, 1971). In this disease the defect of immunity comprises both depression of cellular immunity and a low serum IgA. Consequently, the reports by Sutton, Bishun, and Soothill (1969) and by Chandra (1972) that there are changes in the immunoglobulin levels of the first-degree relatives of children with acute leukaemia suggested the possibility that there might be a change in the immune response in some members of the family of the leukaemic child. This might in some way be a predisposing factor. The present study has attempted to test this possibility by studying the immune response in the sibs and parents of children with acute leukaemia.

\section{Subjects and methods}

33 mothers, 17 fathers, and 14 sibs of children with acute lymphoblastic leukaemia were tested together with

Received 23 October 1972.
15 control mothers and 13 control children. Only 3 control fathers were studied. The prefix 'AL' denotes a relative of a child with acute lymphoblastic leukaemia (ALL).

The average age of the mothers was 33.5 years for AL mothers and 33 years for the controls. The AL sibs had an average age of 10 years and the control group had an average age of 7.4 years. The controls were children attending a haematology clinic with their parents on account of diseases not expected to produce changes in the immune response; many had congenital heart disease. A blood count and calculation of the absolute lymphocyte count were made. Blood grouping was performed using standard methods, and titres of anti-A and anti-B were measured by agglutination at room temperature after 2 hours with a microtechnique using a pool of fresh A1 and B cells, reading the endpoint microscopically. The test and control sera were frozen and read in three separate batches. Immunoglobulin levels were estimated using Hyland Immunoplates, controlled by a reference standard of pooled normal serum which had been calibrated against the Medical Research Council's provisional standard serum by Dr. R. A. Thompson. Lymphocyte transformation rates were measured visually by a modification of the method of Pentycross (1968). Assessment of antibody to herpes simplex virus was made by complement fixation by Dr. P. Sequeira, and levels of antibody to Epstein-Barr virus were assessed by both complement fixation and fluorescence by Dr. R. N. P. Sutton (Sutton, Marston, and Emond, 1971b; Sutton et al., 1971a). Inquiries were also made for a family history of allergy in view of reports that malignant disease is less frequent in individuals with a history of allergy (Fisherman, 1960; MacKay, 1966). 
TABLE I

Mean immunoglobulin levels of mothers, fathers, and sibs of children with acute lymphoblastic leukaemia

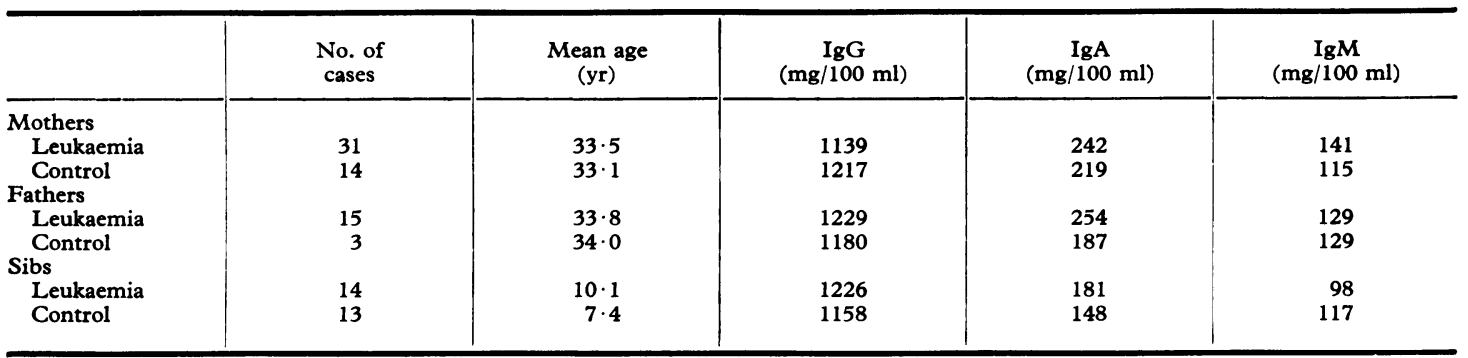

Note: The differences between 'leukaemia' and 'control' results were not statistically significant.

\section{Results}

Of the control families, $27 \%$ gave a history of allergy either in the patients' sibs or in first-degree relatives of the parents. $34 \%$ of the $\mathrm{AL}$ families were positive. The differences were not significant; it is unlikely that a family history of allergy has any bearing on childhood leukaemia.

The blood groups showed the expected number of cases of individuals of group $A$ and group $O$. The median anti-A and anti-B titres of the mothers were as follows. Group $\mathrm{O}$, anti-A 1/256, anti-B 1/64 (control $1 / 96$ and $1 / 48$ ); group $A$, anti-B $1 / 64$ (control 1/32). These maternal titres were higher than in controls but the differences were not significant and were very close to the mean levels for adults aged 30 to 55 (anti-A 1/250, anti-B 1/80) reported in 1929 by Thomsen and Kettel. The results in fathers and sibs were likewise normal.

The serum immunoglobulin levels are shown in Table I. The differences are not significant.

The results of the lymphocyte transformation tests are shown in Table II. Apart from one father with a low count $(47 \%)$, the results are all in the normal range. The means are slightly lower in the case of mothers, fathers, and children, but the
TABLE II

Lymphocyte transformation with phytohaemagglutinin: parents and sibs of children with acute lymphoblastic leukaemia

\begin{tabular}{|c|c|c|c|c|}
\hline & $\begin{array}{c}\text { Range } \\
(\%)\end{array}$ & $\begin{array}{c}\text { Mean } \\
(\%)\end{array}$ & $\begin{array}{c}\text { No. of } \\
\text { cases }\end{array}$ & \\
\hline $\begin{array}{l}\text { Mothers } \\
\text { Leukaemia } \\
\text { Control }\end{array}$ & $\begin{array}{l}53-93 \\
64-94\end{array}$ & $\begin{array}{l}74 \\
78\end{array}$ & $\begin{array}{l}30 \\
15\end{array}$ & $0.1<\mathrm{P}<0.2$ \\
\hline $\begin{array}{l}\text { Fathers } \\
\text { L.eukaemia } \\
\text { Control } \\
\text { Sibs }\end{array}$ & $\begin{array}{l}47-92 \\
65-86\end{array}$ & $\begin{array}{l}74 \\
79\end{array}$ & $\begin{array}{r}15 \\
3\end{array}$ & $0.4<P<0.5$ \\
\hline $\begin{array}{l}\text { Leukaemia } \\
\text { Control }\end{array}$ & $\begin{array}{l}61-96 \\
57-89\end{array}$ & $\begin{array}{l}71 \\
75\end{array}$ & $\begin{array}{l}12 \\
13\end{array}$ & $0.3<\mathrm{P}<0.4$ \\
\hline
\end{tabular}

differences are not significant, either individually or for the group.

Complement fixation tests for antibody to herpes simplex and Epstein-Barr virus are shown in Table III. The usual titre against herpes simplex for a positive adult is $1 / 32$ or $1 / 64$. The median titres in fathers and mothers are normal. 4/31 AL mothers and 4/17 AL fathers had no herpes antibody, and in each case both parents in the family were negative.

TABLE III

Median titres of antibody against Epstein-Barr virus and herpes simplex in parents and sibs of children with acute lymphoblastic leukaemia (number of cases in brackets)

\begin{tabular}{|c|c|c|c|c|c|c|c|}
\hline & \multirow{2}{*}{$\begin{array}{c}\text { Mean } \\
\text { age } \\
(y r)\end{array}$} & \multirow{2}{*}{\multicolumn{2}{|c|}{$\begin{array}{l}\text { Herpes simplex } \\
\text { complement } \\
\text { fixation }\end{array}$}} & \multicolumn{4}{|c|}{ Epstein-Barr virus } \\
\hline & & & & \multicolumn{2}{|c|}{ Fluorescence } & \multicolumn{2}{|c|}{$\begin{array}{l}\text { Complement } \\
\text { fixation }\end{array}$} \\
\hline $\begin{array}{l}\text { Leukaemia } \\
\text { Controls } \\
\text { Sibs } \\
\text { Leukaemia } \\
\text { Controls }\end{array}$ & $\begin{array}{l}33 \cdot 5 \\
34 \\
\\
10 \cdot 1 \\
7 \cdot 4\end{array}$ & $\begin{array}{r}1 / 64 \\
1 / 48 \\
\\
1 / 16 \\
<1 / 8\end{array}$ & $\begin{array}{l}(48) \\
(16) \\
(13) \\
(12)\end{array}$ & $\begin{array}{l}1 / 32 \\
1 / 48 \\
1 / 16 \\
1 / 16\end{array}$ & $\begin{array}{l}(33) \\
(14) \\
(12) \\
(11)\end{array}$ & $\begin{array}{l}1 / 48 \\
1 / 24 \\
1 / 32 \\
1 / 48\end{array}$ & $\begin{array}{l}(33) \\
(14) \\
(12) \\
(10)\end{array}$ \\
\hline
\end{tabular}


The median titre for children was lower at $1 / 16$, reflecting the lower incidence of infection in the younger age group. The absence of antibody in the majority of the control children is probably due to the lower mean age of this group. Only one family was found with lack of antibody in parents and a sib, i.e. two generations. No results were available for sibs of the other 3 sets of parents without antibody. None of these patients had immunoglobulin deficiency and hence this probably indicates absence of infection by herpes simplex in these families, rather than a reflection of immunological defect.

Of the parents tested for Epstein-Barr virus, all had antibody (22/22 mothers, 11/11 fathers) as complement-fixing antibody, though 4 mothers and 1 father lacked fluorescent antibody. 1 of $12 \mathrm{AL}$ sibs lacked antibody, and 1 was positive only by complement fixation. 1 of 11 control sibs lacked antibody. There is no evidence of lack of response to Epstein-Barr virus in leukaemia families, and median titres by both complement-fixing and fluorescent antibody methods for parents and sibs show no great difference from the controls. Sutton et al., (1971b) showed positive complement-fixing titres against Epstein-Barr virus in $89 \%$ of hospital patients over the age of 25 and in $75 \%$ of nurses and medical students aged 24 to 28, with lower percentages in younger subjects. If, as seems likely, the incidence of antibody to Epstein-Barr virus rises with the age of the population tested, it is not surprising that the incidence of antibodies in the leukaemia parents, whose average age was about 33 years, was $100 \%$. Antibody was also present in $100 \%$ of the control mothers and fathers. No one had an abnormally high antibody titre (about $1 / 256$ ) as reported in some patients with Burkitt's tumour (Sutton et al., 1971b).

Lymphocyte counts were made to see if there was any reduction of peripheral blood lymphocytes, as is found in some cases with impaired cellular immunity. No one showed lymphopenia, but counts were higher in the AL families than in the controls, and higher than the mean of $2500 / \mu 1$ usually quoted (Dacie and Lewis, 1968). The mean lymphocyte counts with the initial data were as follows: mothers ( 33 cases) $3463 / \mu 1$, fathers ( 17 cases) $3470 / \mu 1$, compared with controls ( 15 female + 3 male) $2422 / \mu 1$. The AL sibs were similarly raised (14 cases) 5433/ $\mu$ l compared to controls (13 cases) $3056 / \mu 1$. The differences are significant for mothers and sibs $(P<0.01$ and $0.01<P<0.02$, respectively).

This was an unexpected finding, and the results were checked against the other counts performed in the laboratory at the same time. The counts were made from late November 1969 to January 1970, whereas the controls were tested between January and May 1970. All were performed by the same technician along with day-to-day counts. The average total leucocyte count for children in the hospital at the time these tests were made was

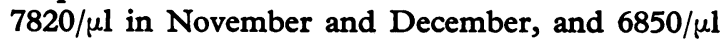

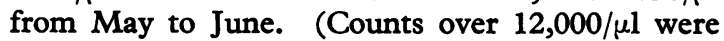
excluded from these calculations as being an abnormal leucocytosis.) The winter increase of 970 cells is not enough to explain the difference, which amounts to 1099 in the case of the mothers. On two days the counts appeared to be higher than the average, and the figures were recalculated omitting the counts made on these days as possibly due to laboratory errors. The sib counts are also omitted, as there is a greater variation in children's blood counts due to age; but a lymphocytosis is still apparent for mothers and fathers (Table IV). The

TABLE IV

Lymphocyte counts of mothers and fathers of children with acute lymphoblastic leukaemia

\begin{tabular}{|c|c|c|c|c|}
\hline & \multirow{2}{*}{$\begin{array}{l}\text { No. of } \\
\text { cases }\end{array}$} & \multicolumn{3}{|c|}{ Lymphocytes/ul } \\
\hline & & Mean & Range & Difference \\
\hline Mothers & 27 & 3329 & $1820-5520$ & \\
\hline Controls & $\begin{aligned} 17(\mathbf{M}=3) \\
\quad(\mathrm{F}=14)\end{aligned}$ & 2228 & $1030-3350$ & $P<0.002$ \\
\hline Fathers & 12 & 3028 & $1500-4860$ & \\
\hline
\end{tabular}

Note: Recalculated as described in the text.

lymphocyte counts of 10 mothers were retested approximately 20 months later. The mean initial count was high $(3620 / \mu l)$, but the second count $(2770 / \mu l)$ was within the normal range.

\section{Discussion}

These investigations into the immune status of the relatives of children with acute lymphoblastic leukaemia (ALL) were prompted by the report of Sutton et al. (1969) that mean levels of IgM in the blood of mothers of leukaemic children were significantly raised, and that levels of IgA in the sibs were significantly reduced. Further evidence that immunoglobulin levels in the families of children with ALL are abnormal was given by the reports of Snyder et al., (1970) and Chandra (1972). The one consistent finding in all these reports has been the presence of a raised level of IgM in the mothers of 
leukaemic children. There has been no consistent pattern of change for other maternal immunoglobulins, or for immunoglobulin changes in the serum of sibs, e.g. Sutton et al. (1969) found sibs to have low IgA and Chandra (1972) found them to have low IgG. The mean level of maternal IgM in the present study was also raised, but this was not statistically significant.

The serum antibody levels to herpes simplex and Epstein-Barr viruses show evidence of response in the families. Both are DNA viruses of the herpes group, and such viruses may be tumorigenic in animals (Epstein, 1971). There is no correlation between the presence of complement-fixing antibodies to herpes simplex or of complement-fixing and fluorescent antibodies to Epstein-Barr virus. In 4 families both parents lacked antibody to herpes simplex. The incidence of Epstein-Barr virus antibodies in the parents was $100 \%$ by the complement-fixing method (22/22 mothers positive, 11/11 fathers positive). But it is unlikely that infection with Epstein-Barr virus is a prerequisite for the development of childhood leukaemia, as $6 / 24$ with ALL had no complement-fixing antibodies to Epstein-Barr virus though their mothers were positive for both complement-fixing and fluorescent antibodies (R. N. P. Sutton and D. I. K. Evans, 1971, unpublished observations). We may conclude that the parents of leukaemic children are able to produce normal amounts of antibody to these common viruses and that the humoral response against virus infection is normal.

Nevertheless, it is clear that viral infection during pregnancy may be related to the subsequent development of malignant disease in the offspring: Stewart, Webb, and Hewitt, (1958) reported an excess of mothers of children with cancer having had a viral illness in pregnancy compared with controls. Fedrick and Alberman (1972) estimated that the risk of developing tumours of haemopoietic and lymphatic tissue among children whose mothers had influenza during pregnancy was fourfold, and of the 8 children they reported whose mothers were affected in this way, 6 were cases of acute lymphoblastic leukaemia.

The theory that maternal viral infection relates to childhood ALL is given indirect support by the unexpected finding of a lymphocytosis in the leukaemia families. Studies in the early days of haematology failed to show any seasonal difference in the leucocyte count, though the 'afternoon tide' is well recognized, counts being higher in the afternoon (Britton, 1969). These counts were almost all made in the morning. M. Till and R. M. Hardisty (personal communication, 1971) also found a lym- phocytosis in the mothers of children with acute leukaemia attending a clinic. They attributed this to stress, as, on a further visit with a friend, the lymphocyte count was found to be normal. The second count in 10 mothers studied here was also normal. But if stress has any part to play in causing a raised lymphocyte count, it is a short-lived effect. The lymphocytosis induced by injection of adrenaline produces an initial lymphocytosis for less than 1 hour and is rapidly succeeded by a neutropenia followed by a smaller lymphocyte peak at 3 to 4 hours (Gabrilove, et al., 1949; Samuels, 1951; Steel, French, and Aitchinson, 1971). Further studies into the lymphocyte counts of leukaemia families are proposed. They are relevant because bovine leucosis, which is a lymphosarcomatous disease of cattle, spread horizontally by contact and vertically by transplacental spread and transfer in milk, is characterized by the presence of a lymphocytosis in some otherwise normal cattle in an infected herd (Götze, Rosenberger, and Ziegenhagen, 1954; Bendixen, 1963).

\section{Conclusion}

There appears to be no evidence of a defect in any limb of the immune response in the families of children with acute lymphoblastic leukaemia which can be shown by the tests used here. In every case the AL families gave a normal result. In other studies, a consistent finding has been a significant increase of IgM in the mothers of leukaemic children, which was not found in the present study.

The lymphocytosis found in these families calls for further investigation.

I am grateful to Drs. P. J. L. Sequeira, and R. N. P. Sutton for virus antibody studies; to Mrs. L. MacElroy and Mrs. C. O'Rourke for technical help; to Mrs. Carol Bowman, Mrs. Suzanne Trew, and Mr. K. Palmer for statistical analyses. The work was supported by a grant from the Leukaemia Research Fund.

\section{REFERENCES}

Ablin, R. J. (1971). Selective deficiency of IgA. Lancet, 2, 378. Bendixen, H. J. (1963). Leukosis enzootica bovis: Diagnostik, Epidemiologi, Bekaempelse. Thesis, Copenhagen.

Britton, C. J. C. (1969). Disorders of the Blood, 10th ed. Churchill, London.

Chandra, R. K. (1972). Serum immunoglobulin levels in children with acute lymphoblastic leukaemia and their mothers and sibs. Archives of Disease in Childhood, 47, 618.

Dacie, J. V., and Lewis, S. M. (1968). Practical Haematology, 4th ed., p. 13. Churchill, London.

Epstein, M. A. (1971). The possible role of viruses in human cancer. Lancet, 1, 1344.

Fedrick, J., and Alberman, E. D. (1972). Reported influenza in pregnancy and subsequent cancer in the child. British Medical fournal, 2, 485.

Fisherman, E. W. (1960). Does the allergic diathesis influence malignancy? fournal of Allergy, 31, 74 . 
Gabrilove, J. L., Volterra, M., Jacobs, M. D., and Soffer, L. J. (1949). The effect of the parenteral injection of epinephrin on leucocyte counts in normal subjects and in patients with Addison's disease. Blood, 4, 646 .

Gatti, R. A., and Good, R. A. (1971). Occurrence of malignancy in immunodeficiency diseases: a literature review. Cancer, 28, 89.

Goldberg, L. S., Barnett, E. V., and Fudenberg, H. H. (1968). Selective absence of IgA: a family study. Fournal of Laboratory and Clinical Medicine, 72, 204.

Götze, R., Rosenberger, G., and Ziegenhagen, G. (1954). Die Leukose des Rindes. Ihre hämatologische und klinische Diagnose. Monatshefte für Veterinärmedizin, 9, 517.

MacKay, W. D. (1966). The incidence of allergic disorders and cancer. British fournal of Cancer, 20, 434.

Pentycross, C. R. (1968). Technique for lymphocyte transformation. Fournal of Clinical Pathology, 21, 175.

Samuels, A. J. (1951). Primary and secondary leucocyte changes following the intramuscular injection of epinephrine hydrochloride. Fournal of Clinical Investigation, 30, 941.

Snyder, A. L., Li, F. P., Henderson, E. S., and Todaro, G. J. (1970). Possible inherited leukaemogenic factors in familial acute myelogenous leukaemia. Lancet, 1, 586.

Soothill, J. F. (1968). Immunoglobulins in first-degree relatives of patients with hypogammaglobulinaemia. Transient hypogammaglobulinaemia; a possible manifestation of heterozygosity. Lancet, 1, 1001.

Steel, C. M., French, E. B., and Aitchinson, W. R. C. (1971). Studies on adrenaline-induced leucocytosis in normal man. I.
The role of the spleen and of the thoracic duct. British fournal of Haematology, 21, 413.

Stewart, A., Webb, J., and Hewitt, D. (1958). A survey of childhood malignancies. British Medical fournal, 1, 1495.

Stocker, F., Ammann, P., and Rossi, E. (1968). Selective $\gamma-A-$ globulin deficiency, with dominant autosomal inheritance in a Swiss family. Archives of Disease in Childhood, 43, 585 .

Sutton, R. N. P., Almond, E. J. P., Marston, S. D, and Emond, R. T. D. (1971a). Complement-fixing and fluorescent antibodies in diagnosis of E.B.-virus infections. Lancet, 2, 1095.

Sutton, R. N. P., Bishun, N. P., and Soothill, J. F. (1969), Immunological and chromosomal studies in first-degree relatives of children with acute lymphoblastic leukaemia. British fournal of Haematology, 17, 113.

Sutton, R. N. P., Marston, S. D., and Emond, R. T. D. (1971b) Some observations on complement-fixing antibodies to the E.B. virus. Fournal of Clinical Pathology, 24, 801.

Thomsen, O., and Kettel, K. (1929). Die Stärke der menschlichen Isoagglutinine und entsprechenden Blutkorperchenrezeptoren in verschiedenen Lebensaltern. Zeitschrift für Immunitätsforschung und experimentelle Therapie, 63, 67.

Correspondence to Dr. D. I. K. Evans, Royal Manchester Children's Hospital, Pendlebury, Manchester M27 1HA. 